NBER WORKING PAPER SERIES

\title{
PROTECTION REDUCTION AND DIVERSION: PTAS AND THE INCIDENCE OF ANTIDUMPING DISPUTES
}

\author{
Thomas J. Prusa \\ Robert Teh \\ Working Paper 16276 \\ http://www.nber.org/papers/w16276 \\ NATIONAL BUREAU OF ECONOMIC RESEARCH \\ 1050 Massachusetts Avenue \\ Cambridge, MA 02138
}

August 2010

The opinions expressed in this paper should be attributed to the authors. They are not meant to represent the positions or opinions of the WTO and its Members and are without prejudice to Members' rights and obligations under the WTO. We would like to thank Philippa Dee for generously providing us with her tabulation of investment provisions in PTAs. The paper has also benefitted from the many helpful comments from seminar participants at University of Connecticut, New York Federal Reserve, Villanova University, CUNY Graduate Center, World Trade Organization, Stockholm University, Institut d'Études Politiques de Paris (Sciences-Po), and Inter-American Development Bank. All remaining errors and omissions are the fault of the authors. The views expressed herein are those of the authors and do not necessarily reflect the views of the National Bureau of Economic Research.

NBER working papers are circulated for discussion and comment purposes. They have not been peerreviewed or been subject to the review by the NBER Board of Directors that accompanies official NBER publications.

(C) 2010 by Thomas J. Prusa and Robert Teh. All rights reserved. Short sections of text, not to exceed two paragraphs, may be quoted without explicit permission provided that full credit, including $\odot$ notice, is given to the source. 
Protection Reduction and Diversion: PTAs and the Incidence of Antidumping Disputes

Thomas J. Prusa and Robert Teh

NBER Working Paper No. 16276

August 2010

JEL No. F1,F5

\section{$\underline{\text { ABSTRACT }}$}

We analyze whether preferential trade agreements (PTAs) affect the incidence and pattern of antidumping (AD) filings. We estimate AD provisions in PTAs have decreased the incidence of intra-PTA AD cases by $33-55 \%$ and have increased the number of AD actions against non-PTA members by $10-30 \%$. The net effect of PTA rules on total AD filings is small. Our results are robust to alternative estimation approaches and controlling for a myriad of other PTA-related phenomena. Our results suggest a protection analogue to the "trade creation-trade diversion" impact of PTAs. PTA members are spared from AD actions but non-PTA members face even greater AD scrutiny.

Thomas J. Prusa

Department of Economics

New Jersey Hall

Rutgers University

New Brunswick, NJ 08901-1248

and NBER

prusa@econ.rutgers.edu

Robert Teh

Economic Research and Statistics Division

WTO

Centre William Rappard

Rue de Lausanne 154

CH-1211 Geneva 21, Switzerland

robert.teh@wto.org 


\section{Introduction}

Tariff reductions are a key aspect of any preferential trading agreement (PTA), but they are usually just one part of the overall agreement. ${ }^{1}$ Competition policy, labor mobility, right-towork rules, investor protections, sectoral carve-outs, services liberalization, technical barriers to trade and rules-of-origin are just some of the provisions often found in such agreements. Any of these rules can have a significant impact on trade patterns (Estevadeordal, Suominen and Teh, 2009).

While it is well known that preferential tariffs discriminate against non-members it is not clear whether other PTA policies accentuate or attenuate this discrimination. In this paper we empirically explore the possibility of additional discrimination via PTAs by focusing on the extent to which PTAs alter the pattern of antidumping (AD) activity. AD is a particularly apt policy to study not only because it is the most frequently used administrative trade policy but also because there is considerable variation in AD rules across PTAs. Some PTAs contain no AD provisions, some prohibit its use, and others contain special rules for its use.

We find that PTAs have a significant impact on the pattern of protection, tilting the playing field further in favor of member countries. AD provisions in PTAs have decreased the number of intra-PTA AD cases by 33-55\% and increased the number of AD actions against nonPTA members by $10-30 \%$. On net, PTAs have had a modest impact on the total number of AD initiations.

Our results demonstrate a protection analogue to the well known "trade creation-trade diversion" impact of PTAs. While PTA members are spared from AD actions ("protection reduction”), non-PTA members face even greater AD scrutiny (“protection diversion”). While Bhagwati (1992, 1993) and Bhagwati and Panagariya (1996) conjectured such a protection pattern could emerge from PTAs, our results provide the first empirical support for their hypothesis.

We believe our study is especially relevant given the prominence that both AD and PTAs currently play in the trade policy arena. Antidumping has long been the trade remedy of choice.

\footnotetext{
${ }^{1}$ We use the term "preferential trade agreement" broadly. We use the term PTA to refer to free trade areas and customs unions, in addition to agreements more strictly referred to as preferential trade arrangements.
} 
In the 1980s there were more AD actions than under all other trade statutes combined (Prusa, 2000) and to this day AD continues to dwarf all other trade remedies. Over the past fifteen years, AD cases account for an amazing 89 percent of all trade remedy cases (Stevenson, 2009). In fact, AD’s prominence has increased over the past two decades. The number of countries using $\mathrm{AD}$ has increased five-fold and the annual number of $\mathrm{AD}$ disputes has more than doubled (Prusa, 2005). There were more AD disputes in the smallest year during the past decade than during the peak year during the 1980s.

The growth in PTAs is no less astounding. Teh, Budetta, and Prusa (2009) report that between 1980 and 2006 there has been no less than an eight-fold increase in the number of PTAs reported to the World Trade Organization (WTO). Given the challenges of successfully concluding the Doha Round many countries are increasingly turning their attention to bilateral and regional negotiations. There is no reason to think the proliferation of PTAs will soon end.

We begin by comparing filing trends before and after the formation of the PTA and find that intra-PTA initiations fall sharply following the enactment of the PTA. We then extend our analysis to also include AD activity against non-PTA countries. We estimate difference-indifference negative binomial regressions for bilateral filings by each country (country $i$ ) against each trading partner (country $j$ ) in each year. After controlling for other factors that influence AD activity, we find PTAs reduce intra-PTA AD activity and increase filings against non-PTA countries.

One concern is that the effect attributed to AD provisions might indeed be related to PTA membership but not really driven by AD rules. For instance, the PTA might simply engender “good will” or political closeness. We find little support for this hypothesis. PTAs without AD language do not experience any change in AD activity whereas PTAs with AD rules are characterized by protection reduction and protection diversion.

A related concern involves the possibility that it is other PTA provisions that alter the pattern of AD activity. If there is a correlation between a PTA's AD rules and these other rules, then the interpretation of our results might change. We investigate this possibility by focusing on what we think is a likely suspect - PTA investment provisions. PTAs often have rules that facilitate foreign direct investment between PTA members. PTA investment rules might induce investment deepening (i.e. more multinational trade) which in turn might lead to a decrease in $\mathrm{AD}$ petitions. In this scenario, it is possible that $\mathrm{AD}$ activity has fallen not because of the $\mathrm{AD}$ 
provisions but rather as a result of greater investment ties between PTA members that change the incentive to seek higher AD duties on PTA members.

We examine this issue by including a measure of the investment liberalization in each PTA agreement (Dee, 2008). We find that investment provisions in PTAs do reduce the incidence of $\mathrm{AD}$ disputes. Nevertheless, we continue to find that $\mathrm{AD}$ rules remain a significant independent explanation for the reduction in intra-PTA AD cases. As a robustness check, we also use OECD foreign direct investment flow data to measure the investment deepening hypothesis. We again confirm the impact of AD rules.

We then undertake a large number of robustness checks. We consider a variety of alternative specifications - year effects, bilateral investment incentives, the impact of China, an alternative classification of AD rules, fixed and unbalanced panels - and find no significant change in our findings. Following Bertrand, Duflo, and Mullainathan (2004) we also control for the possibility of inconsistent estimates due the panel nature of our data; our results remain large and statistically significant.

\section{Antidumping and PTAs}

Since the WTO’s Antidumping Agreement already defines AD procedures we presume the additional rules incorporated in PTAs will not weaken the existing rules governing AD actions. ${ }^{2}$ Nevertheless, it is not obvious that PTA provisions will reduce the amount of AD activity. First, recent research has emphasized the discretionary power of authorities (Blonigen and Prusa, 2003; Horlick and Vermulst, 2005; Blonigen, 2006; Moore and Fox, 2010). These papers argue that $\mathrm{AD}$ rules are sufficiently vague and give decision-makers considerable latitude in making their protection decisions; these papers cast doubt on the notion that PTA provisions will change how the bureaucratic agencies make decisions or alter how industries seek protection. Second, even if the provisions matter it is unclear whether the measured effect will be economically significant. In some agreements, the new provisions appear to be quite weak and may not have any practical effect. In others, however, the provisions "raise the bar" by restricting how dumping margins are computed, by mandating more restrictive injury and causation standards, by limiting the duration of duties, by expanding the scope for firms to

\footnotetext{
${ }^{2}$ Given the pre-existing WTO rules, such provisions in PTAs are often referred to as "WTO plus" rules.
} 
resolve the conflict via negotiations, by providing additional opportunities for the foreign firm to appeal the decision, etc.

We reviewed legal provisions governing trade remedies in 80 PTAs. ${ }^{3}$ To our knowledge our database is the most comprehensive review of PTA AD provisions ever undertaken. We reviewed all economically significant PTAs reported to the WTO through 2008. The PTAs were chosen based on economic importance, accessibility of information and language. While there are many PTAs not in our sample, the excluded PTAs generally involve small amounts of trade and have few provisions beyond tariff reductions.

The coverage of our database is impressive: almost 50\% of all worldwide exports are accounted for by the PTAs in our sample. The database captures the vast majority of PTAaffected trade and includes the two largest PTAs, the EU and NAFTA. The list is geographically diverse with PTAs from North America, the Caribbean, Latin America, Asia and the Pacific, Africa, the Middle East, Western Europe and Central and Eastern Europe.

We classified PTAs into three mutually-exclusive groups: (i) those with no AD provisions; (ii) those that prohibit the use of $\mathrm{AD}$; and (iii) and those that include some language pertaining to $\mathrm{AD} .{ }^{4}$ In Table 1 we list the 80 PTAs in our sample (alphabetical order). We also include information on the starting year of the PTA. Nine PTAs, including such notables as the EC/EU, EFTA, CER, EEA, Canada-Chile, and EFTA-Singapore, have prohibited the use of AD; 54 PTAs include special AD rules; 17 PTAs include no discussion of AD.

We note that some of the PTAs were enacted before we have any information on AD filings (e.g., EC/EU). In this study, as in almost all other studies, we have information on AD actions only since the end of the Tokyo Round. ${ }^{5}$ To some extent, this lack of information on pre1980 AD will hinder our ability to accurately assess the impact these early PTAs have had on AD activity. For this handful of early PTAs we will only be able to assess the impact by comparing AD filings against PTA and non-PTA members and cannot compare the propensity to file AD cases pre- and post-PTA.

\footnotetext{
${ }^{3}$ This is greater than the number of PTAs covered in Teh, Budetta and Prusa (2009).

${ }^{4}$ For this third category of PTAs, an additional template was developed which includes specific information on the rules included in the PTA. Teh, Budetta and Prusa (2009) offer a complete description of the trade remedy mapping.

${ }^{5}$ Irwin (2005) is the only paper we are aware of that utilizes pre-1980 AD filings. His analysis is limited to just U.S. filings.
} 
Using official country AD reports to the WTO we collected information on the number of AD cases filed since 1980. Over this period 5,006 AD filings were initiated. Of this total, only 201 were initiated by countries that are not members of any PTA and hence are dropped. This leaves us a sample of 4,805 AD filings, 745 (4,060) of which were taken against PTA (non-PTA) members.

\section{A First Look at the Data}

We begin by looking at the trends in intra-PTA AD usage. For each country we calculate the annual number of AD cases initiated by each PTA member against fellow PTA members. For the moment, we will ignore trends in AD use by PTA members against non-PTA members and AD usage by countries not in any PTAs. Given that PTAs are enacted in a variety of years, we abstract from calendar time and instead consider time as measured relative to the year the PTA was enacted. For each PTA, year zero is the year the PTA was enacted, year $t-1$ is the year before, year $t-2$ is two years before enactment, $t+1$ is the year after, etc. This view of time allows us to conveniently aggregate across PTAs.

In Figure 1 we plot the aggregate number of AD disputes relative to each PTA's inception (panel a). Two comments are in order. First, the raw data provides compelling support for the protection reduction hypothesis. During the years prior to the PTA enactment, intra-PTA $\mathrm{AD}$ activity is growing. The number of $\mathrm{AD}$ disputes drop sharply in the enactment year $(t=0)$ and remain much lower in subsequent years as compare to the years prior to enactment. On average, during the 10 years prior to enactment there were $29.5 \mathrm{AD}$ cases per year and during the 10 years following enactment there were just 23.6 cases per year. Second, the dispute data shows evidence of macroeconomic cyclicality. Knetter and Prusa (2003) argue GDP trends are an important factor for $\mathrm{AD}$ filings; we will control for this issue in our regressions.

One deficiency with this graph is the unbalanced nature of the data. For PTAs that emerge late in our sample we observe many years prior to enactment but only a few years post enactment. Since a large number of PTAs were enacted in the last decade an unbalanced panel analysis depicted in Figure 1(a) might show there was a decrease in activity following the PTA but the reduction could in fact be caused by fewer observations in the post-PTA period. 
We can control for this potential bias by restricting each PTA to the same number of years before and after enactment. In the next two panels in Figure 1 we restrict our sample to just those PTAs who we have all relevant data for either 3 or 6 years before and after enactment. In both samples we see strong evidence that PTAs reduce intra-PTA filings. In Figure 1(b) we see that if we look just at PTAs with information +/- 3 years there were 38.3 cases per year before as compared to just 14.5 following the PTA. If we expand the horizon and look just at PTAs with information +/- 6 years we see the there were 19.7 cases per year before versus just 8.6 following the PTA (Figure 1(c)). Both figures offer compelling support for the protection reduction hypothesis.

While the results are intriguing we have not yet controlled for the possibility that $\mathrm{AD}$ activity against all source countries may have fallen at a time coincidental with the enactment of the PTA. The above figures do not distinguish the PTA from some other trend. For instance, given that the Uruguay Round was concluded in 1994 and given that a number of PTAs were enacted in the mid-1990s, we cannot guarantee that the observed decline in AD activity might be a result of $\mathrm{AD}$ provisions in the Uruguay Round.

NAFTA exemplifies the potential issue. In Figure 2 we plot the annual number of AD disputes filed by NAFTA countries breaking out cases targeting NAFTA and non-NAFTA countries. As seen, beginning around the time of the enactment, intra-NAFTA filings fall sharply. On average, there were 14.6 AD disputes per year between NAFTA members in the decade prior to NAFTA but only 6.9 disputes per year in the decade following NAFTA. The figure also shows a decrease in AD filings by NAFTA members against non-NAFTA countries. On average, there were 70.4 AD filings per year by NAFTA members against non-NAFTA suppliers in the decade prior to NAFTA and 51.6 filings per year in the decade following NAFTA. While the figure suggests the fall has been greater for PTA members, it is clear that we need to control for the overall pattern of protection.

Difference-in-difference is the simplest and best known method for controlling for such issues. The simplest set up is one where we observe disputes for two groups (PTA and nonPTA) for two time periods (pre and post). In this application the PTA countries are "treated" to some additional AD rules that possibly affect activity in the post-PTA period but not in the prePTA period. The non-PTA countries are not exposed to the treatment during either period. The results from this simple difference-in-difference method are given in Table 2. As seen, countries 
file about $58 \%$ of AD cases against non-PTA countries prior to PTA enactment but an impressive $90 \%$ following enactment. ${ }^{6}$

All of these informal analyses of the filing trends suggest that PTAs alter the pattern of AD activity. We now turn to identifying exactly what characteristics of PTAs generate these patterns.

\section{Impact of PTAs - Difference in Difference Estimates}

\subsection{Background}

We estimate the impact of PTAs on AD filings by running a difference-in-difference (DiD) regression of the form

$v_{i j t}=\beta_{0}+\beta_{1} P T A_{i j}+\beta_{2} \operatorname{POST}_{i j t}+\beta_{3}\left(P T A_{i j} * P O S T_{i j t}\right)+\lambda X_{i j t}+\varepsilon_{i j t}$,

where $v_{i j t}$ denotes the count of AD disputes filed by country $i$ against import source $j$ in year $t$, $P T A_{i j}$ is a dummy variable indicating whether $i$ and $j$ are members of the same PTA, POST $i j t$ is a dummy variable whether the PTA is in effect in year $t$, and $X_{i j t}$ denotes a vector of exogenous factors that influence trade disputes between countries. $\beta_{1}$ captures the difference in between members and non-members and $\beta_{2}$ represents the difference over time. Beyond this baseline time change, we can examine whether subsequent to the PTA, members have experienced a different trend from non-PTA members, the difference-in-difference $\left(\beta_{3}\right)$.

Given that our dependent variable is the count of disputes, it is inappropriate to use OLS. We instead assume that AD petitions across countries and time follow a discrete distribution, such as Poisson or negative binomial,

$v_{i j t}=e^{\beta_{0}+\beta_{1} P T A_{i j}+\beta_{2} P_{P S T} T_{i j t}+\beta_{3}\left(P T A_{i j}^{*}{ }^{*} O S T_{i j t}\right)+\lambda X_{i j t}}$.

The Poisson distribution imposes a restriction that the variance of the dependent variable is equal to the mean of the dependent variable, whereas the negative binomial distribution allows

\footnotetext{
${ }^{6}$ The p-value for this difference is 0.0000 using the binomial test.
} 
the variance to differ from the mean. Often, count data exhibit over-dispersion with respect to the Poisson model, i.e., the variance of the observed counts exceeds their mean. For our data the equivalence required by the Poisson distribution is clearly rejected. Hence, we estimate using the negative binomial distribution with random effects. ${ }^{7}$ Also, because of the concerns about the unbalanced time series nature of the panel, our baseline estimates restrict each pair of counties to the same number of years before and after the PTA enactment.

There have been a number of previous papers that have statistically examined the factors that determine frequency of U.S. AD actions, and we follow this literature in determining appropriate explanatory variables. ${ }^{8}$ Knetter and Prusa (2003) and Blonigen (2005) are the two most closely related papers to the approach taken here. The variables we use to measure pressure for $\mathrm{AD}$ protection -foreign and domestic GDP, the real exchange rate, and bilateral imports - are rooted in these papers.

Knetter and Prusa (2003) examine the factors that affect AD annual filings for Australia, Canada, the EU and the U.S. They argue that AD filings should increase for a country in years after lower GDP growth. Lower GDP growth makes it more likely that the government agencies will find that there is injury to the domestic industry and this increases the incentives for the domestic industry to file an AD case. Lower GDP in the foreign country might make it more likely the foreign firm will sell exports at dumped prices. They also study the effect of changes in the real exchange rate on AD filings. They show that although in theory an appreciation of the real exchange rate may either increase or decrease AD filings, in practice real exchange rate appreciations lead to greater AD filings for all four countries in their sample. Blonigen (2005) examines the effect of NAFTA on U.S., Canada, and Mexico's use of AD and argues that the value of bilateral imports is an effective control for macroeconomic pressure for disputes.

The literature also guides us in the choice of the lag structure for these variables. Prusa and Knetter argue the longer lag structure for GDP is related to the statutory requirements that the economic injury determination be calculated over a longer time horizon, typically three years; the dumping calculation which is affected by the exchange rate is normally calculated using a one-year window.

\footnotetext{
${ }^{7}$ We also estimated the models using fixed effects and found similar results in terms of the statistical and economic significance of the PTA measures. See section 7.

8 See, for instance, Finger, Hall, and Nelson (1982), Feinberg (1989), Feinberg and Hirsch (1989), Moore (1992),

DeVault (1993), Baldwin and Steagall (1994), and Jones (2000).
} 


\subsection{Benchmark Estimates}

Let's begin with Table 3. Here we use a single dummy to capture the PTA impact. We will focus just on specifications A-C (specification D-F will be discussed below). The estimates are reported as "incidence rate ratios" associated with the underlying parameter estimates. The incidence rate ratio (IRR) is the ratio of the counts predicted by the model when the variable of interest is one unit above its mean value and all other variables are at their means to the counts predicted when all variables are at their means. For example, if the IRR for the PTA dummy is 0.70, then the PTA would decrease AD activity by 30\% when all other variables are at their means. The null hypothesis is that the IRR=1, which would imply no relationship between the dependent variable and the regressor.

In specification A we include just the DiD dummies; in specification B we incorporate macroeconomic determinants as modeled in Knetter and Prusa (2003). In specification C we include the value of imports into country $i$ sourced from country $j$ as modeled in Blonigen (2005). The results are quite similar across specifications. The parameter of primary interest is the DiD ("PTA x Post”) parameter. For instance, in Table 3 we see that the bilateral estimates imply that the PTAs reduce the incidence of AD disputes by 57-59\%. The parameter is statistically significant in every specification. The estimated impact is large and is consistent with the trends depicted in Figure 1. We also note that the estimated impact of the exchange rate, GDP, and imports are all consistent with the findings in the earlier literature.

A single PTA dummy is used in all specifications in Table 3 which means we cannot distinguish among the different approaches toward AD across PTAs. Some PTAs prohibit the use of AD against PTA members; others contain no AD rules. We expect a different impact between these two types of PTAs. It is not obvious, however, whether we can expect a difference between PTAs with rules and those without rules. If bureaucratic discretion is as prevalent as the literature suggests, then additional rules might not matter. The decrease attributed to AD provisions may in fact be related to PTA membership but be primarily driven by other PTA-related phenomena. For example, what might matter are not the AD rules but rather the political good will that comes from the enactment of a PTA. Membership in PTAs might result in better relations between countries, stronger political ties and in some cases even outright favoritism toward PTA members. If any of these factors are significant, we could measure less 
intra-PTA AD activity but the reduction could have nothing to do with the explicit AD provisions.

The regressions in Table 4 address these concerns. In these specifications we separate the impact for the three different categories of PTAs. For now we will focus just on specifications A-C. The results confirm AD prohibition essentially eliminates AD activity - an estimated IRR of 0 . Two comments are in order. First, despite these PTAs' official abolishment of $\mathrm{AD}$ there are a very small number of disputes that nonetheless occur after enactment. In some cases this is because there is a long phase-in period for the prohibition; in other cases this is because the "prohibition" excludes certain political sensitive products/industries from the ban. ${ }^{9}$ Second, the lack of statistical significance stems from the small number of observations both before and after the enactment for these PTAs.

We find that the $\mathrm{AD}$ rules lead to a $60-65 \%$ reduction in $\mathrm{AD}$ disputes against PTA members ("PTA - AD Rules x Post"). We also find that PTAs without explicit AD rules experience a statistically insignificant increase in $\mathrm{AD}$ disputes. These findings reject the hypothesis that the PTA effect is due to "good will" rather than rules that affect filings. Across all specifications there is a large difference in the estimated impact for PTAs with rules and those without rules. The results imply that rules matter. PTAs may also engender good will, but as seen from the PTAs without AD rules, good will alone does not result in less AD activity.

\section{Investment Deepening}

PTAs are complex, multifaceted agreements. While tariff reduction might garner the headlines, PTAs are almost always wide reaching accords. In fact, for some PTAs it is arguable that preferential tariffs were among the least important reasons for the agreement. Most PTAs involve dozens of other important policies. If one (or some) of these other provisions are correlated with $\mathrm{AD}$ rules then the decrease attributed to $\mathrm{AD}$ provisions may be in fact related to some other provision.

Investment provisions are a likely candidate. If PTA investment rules induce investment deepening we could observe a decrease in $\mathrm{AD}$ petitions. This is especially likely if the investment deepening is in the form of foreign direct investment. In this case the reason for the

\footnotetext{
${ }^{9}$ In the case of the European Economic Area (EEA) for example, the prohibition on anti-dumping does not apply to agricultural and fishery goods.
} 
fall in AD activity may be due to the fact that imports are sourced from an affiliate of domestic multinational rather than an independent foreign entity.

We examine this issue by controlling for investment incentives and flows. Our first approach involves a numerical measure of the investment liberalization in each PTA agreement. Dee (2008) scoured the texts of the PTAs agreements and scored the investment provisions on 19 different criteria encompassing both the form and content of each agreement. Each criterion was given a numerical score ranging from zero (no liberalization and investor guarantees beyond those in WTO agreements) to one (maximal liberalization and investor protections). Higher values correspond to greater levels of investor protection. We then summarize the multidimensional characterization by averaging the 19 investment criteria to create a unidimensional index. ${ }^{10}$ Assuming that actual FDI flows are correlated with investment incentives, the index will proxy for the investment explanation for the decrease in $\mathrm{AD}$ activity.

Dee's investment index ranges from 0.05 to just over 0.75 . On average, the most liberal services and investment provisions are in CER (Australia-New Zealand), NAFTA and its Latin American clones, European agreements (EU, EFTA, EEA) and Mercosur. On the other hand, low scoring PTAs include SPARTECA (South Pacific Trade and Economic Cooperation Agreement), CACM (Central American Common Market), and ALADI (Latin American Integration Association).

The results are contained in specifications D-F in Tables 3 and 4 . In all but one specification the investment index is statistically insignificant but the point estimate is generally consistent with the hypothesis that higher investment incentives promote FDI which in turn reduce the incentive to file AD actions against PTA members. We should note that when interpreting the IRR for this variable, the range of the investment index is far less than 1 . Looking across specifications, our results suggest that PTAs with strong investment protection experience a modest reduction in $\mathrm{AD}$ disputes relative to those with weak investment provisions.

Importantly, the estimates for the impact of PTAs are about the same as before. The PTA dummy (Table 3) implies a reduction of 45-60\%; in Table 4 where we control for the specific type of PTA we find that PTAs with AD rules experience a 55\%-70\% reduction in AD disputes We continue to find no statistically significant impact for those PTAs without AD rules.

\footnotetext{
${ }^{10}$ The index takes a value of zero prior to the enactment of the PTA.
} 
An alternative and more direct control for this issue is to include the annual flow or stock of foreign direct investment in each year. There are two main challenges with the approach. First, while OECD countries maintain good records of FDI, annual bilateral investment flows are simply not available for most countries in our dataset. As a result, we lose a lot of observations. Second, the timing of the relationship between investment flows and changed incentives is unclear. We expect a trade deepening to occur with a lag, but we have little basis for determining lag length.

Table 5 contains the regressions using the FDI measure. For reference, specification G is the basic specification where we limit ourselves only to country pairs for whom we have FDI data. As seen we lose about half the observations due to lack of bilateral FDI information. Nevertheless, the parameters of primary interest are very similar to the previous estimates. As we look across the other specifications we see that including FDI flows and stocks do not significantly alter our estimates. PTAs with AD rules have about a 50-60\% reduction in AD activity; PTAs without AD rules experience an increase in AD activity (albeit statistically insignificant).

\section{Implications for the Aggregate Number of AD filings}

The estimates imply that PTAs reduce the number of intra-PTA AD cases. There are, however, several reasons why we need to be careful inferring what the estimates mean for aggregate AD activity. First of all, early in the sample period there were only a small number of PTAs; this likely means the impact on overall AD filings is small. Second, as seen in Table 2, intra-PTA AD activity has always accounted for a minority of all cases. Thus, the PTA effect might be large, but since we are measuring from a relatively small base the aggregate effect may be small. Third, the steady growth in AD activity is well documented (Prusa, 2000) and some of this growth in activity could be from AD cases directed at non-PTA members. Nevertheless, the main culprit for the injurious trade may truly be the PTA's preferences and rules.

This type of protection diversion result was conjectured (but not empirically verified) by Bhagwati (1992, 1993) and Bhagwati and Panagariya (1996). They argued that due to its elastic and selective nature, administered protection can increase the risk of trade diversion from PTAs. Bhagwati states 
My belief that FTAs will lead to considerable trade diversion because of modern methods of protection, which are inherently selective and can be captured readily by protectionist purposes is one that may have been borne out in the European Community. It is well known that the European Community has used antidumping actions and VERs profusely to erect Fortress Europe against the Far East. Cannot much of this be a trade-diverting policy in response to the intensification of internal competition among member states of the European Community? (Bhagwati, 1993, p. 37)

So apart from discrimination introduced by preferential tariffs, Bhagwati and Panagariya are concerned that the establishment of PTAs can lead to more discrimination against nonmembers of the PTA through more frequent trade remedy actions. They conjecture that there is a protection analogue to the standard "trade creation-trade diversion" impact of PTAs. PTA members are spared from AD actions but non-PTA members face even greater AD scrutiny. Our parameter estimates can be used to test for their conjecture.

We use the parameter estimates in specification $\mathrm{F}$ in Table 4 to compute the predicted number of AD disputes for each year in our sample and report our findings as five-year averages (Table 6). We perform a counterfactual exercise where we calculate the reduction in disputes stemming from intra-PTA effect (i.e., the DiD parameter). The results are in column 1. As seen until the mid-1990s the effect on overall AD filings is modest, mostly because there were a small number of PTAs. By the end of the period, however, we see that the proliferation of PTAs have resulted in about a 9\% annual reduction in $\mathrm{AD}$ actions.

In column 3 we also incorporate the dispute deterring impact of PTA investment provisions. As discussed above, a PTA contains a large portfolio of policies; one can reasonably argue that the counterfactual calculation of the PTA should also include the investment effect. Our estimates imply that by the end of the period the total effect of AD provisions and investment provisions is almost a $13 \%$ decrease in the annual number of AD disputes. Said differently, investment provisions separately reduce AD activity by about $4 \%$.

We now turn to the Bhagwati-Panagariya hypothesis. According to their theory, contingent protection is driven by imports. ${ }^{11}$ Who is targeted in the AD petition is entirely up to

\footnotetext{
${ }^{11}$ Baldwin and Steagall (1994), Blonigen and Bown (2003, Blonigen and Prusa (2003), and Blonigen (2005) all provide support for this view.
} 
the discretion of the domestic industry. If PTA rules make PTA members more difficult to sanction, then the domestic industry will simply target other sources.

Because PTAs often give rise to a marked increase in bilateral trade we might see an increase in AD protection directed toward non-PTA members. ${ }^{12}$ Following BhagwatiPanagariya, if we imagine a world without PTAs it may also be appropriate to suppose that the increase in imports is also attenuated. For purposes of our counterfactual exercise, we suppose that imports grow at the same rate they did during the 5 years prior to the enactment of the PTA (instead of at their actual growth rate) and then re-compute the implied number of AD cases we would have observed. ${ }^{13}$

The results are shown in columns 2 and 4 in Table 5. The results support the BhagwatiPanagariya hypothesis. There is an increase in $\mathrm{AD}$ cases due to protection diversion. When we incorporate the increase in AD activity toward non-PTA members our view about the impact of PTAs on protection is turned on its head: instead of lowering the number of AD cases we find that PTAs increase the overall amount of AD activity. The reduction is in intra-PTA activity is more than offset by the increases in activity against the far larger set of non-PTA members. By the end of the period our results imply that PTAs have increased the overall number of AD disputes by $6-10 \%$.

Our primary point is not that PTAs increase overall AD activity, but rather that the diversion of $\mathrm{AD}$ toward non-PTA members offsets the reduction in AD toward PTA members. At the bottom on Table 3 and 4 we report the implied change in AD activity by the end of the sample for each specification. For each set of estimates we report both the intra-PTA effect and also the total effect (including protection diversion). In all specifications we find that while there is a substantial intra-PTA reduction there is also a significant offsetting effect due to greater scrutiny of non-PTA countries. For some specifications the net effect is positive and in others it is negative.

Overall, we believe the results provide convincing support for the Bhagwati-Panagariya hypothesis. Namely, to the extent that PTAs adopt special or additional rules on trade remedy actions against members' trade, they can effectively increase the level of discrimination against non-members.

\footnotetext{
${ }^{12}$ Eicher, Henn and Papageorgiou (2010) and Freund (2010) offer fine discussions of PTAs on imports.

${ }^{13}$ We also hold "post PTA" parameter at the value of 1 for this counterfactual.
} 


\section{Robustness Checks}

\section{Difference Estimator}

As an alternative to the difference-in-difference specification, we divided our sample into PTA members and non-PTA members and then simply ran a difference (i.e., pre vs. post) regression for each set of countries separately. The results are given in the top panel of Table 7. The specifications across the columns are exactly the same as those used in Table 3.

As shown, the estimates are quite similar to those in Table 3. The PTA effect continues to be large and is statistically significant. The intra-PTA effect implies a 40-60\% reduction in AD actions. Only in specification $F$ is the effect not statistically significant. The non-PTA effect implies a 14-30\% increase in $\mathrm{AD}$ actions. This is also consistent with the prior results as it implies a significant diversion of AD actions against non-PTA members.

At the bottom panel of Table 7 we report the parameter estimates when we separately estimate the effect for the three types of PTAs (rules, no rules, prohibit). As in the top part of Table 7, we run the regression separately for PTA and non-PTA members. We again find compelling confirmation of our findings. In particular, for PTA members we find rules reduce the incidence of $\mathrm{AD}$ filings by about $60 \%$; PTAs without $\mathrm{AD}$ rules exhibit an increase (albeit statistically insignificant) in filings. For non-PTA members we see an increase in AD filings following the PTA enactment, except for countries in PTA that prohibit AD use. For these countries, non-members also experience a reduction in AD filings.

\section{Year Dummies / Uruguay Round}

Tables 8 and 9 present the results from a plethora of alternative specifications. First, we add year effects in an attempt to absorb the PTA effect. The results are virtually unchanged from our benchmark results.

We also ran a specification where we included a dummy to capture the impact of the Uruguay Round agreement. The Uruguay Round contained a number of amendments to the WTO AD statute. Since all countries in our sample are also WTO members, these amendments might be an alternative explanation for the measured reduction in AD activity. Our DiD estimates are virtually unchanged. 


\section{Other Measures for Investment Incentives}

PTAs are not the only way countries can attempt to improve the investment climate. Bilateral investment treaties (BITS) are quite commonly used. A BIT is an agreement establishing the terms and conditions for private investment by nationals and companies of one state in another state. Most BITs grant investments a number of guarantees (e.g., fair treatment, protection from expropriation, etc.) and allow for some type of dispute resolution mechanism. There were more than 2000 BITS in effect during our sample period.

For each country pair, we created a vector of dummies indicating whether or not a BIT was in effect in each year. We then re-ran our regressions including these dummies and report the DiD parameters in Tables 8 and 9. We find no significant change on the estimated PTA parameters.

\section{Drop China}

Due to our concern about the inordinate influence of China on our results, we drop all observations involving China. The PTA estimates are unaffected.

\section{Drop Prominent PTAs (NAFTA \& EC/EU PTAs)}

We are also concerned about the impact of the most prominent PTAs. Our concern is that these PTAs are big outliers and this is why we find such a large effect of PTA rules. First, we drop NAFTA countries from the sample. We do this because (1) NAFTA countries are among the largest users of AD, (2) intra-NAFTA AD activity has significantly fallen, and (3) NAFTA is the largest PTA with AD rules. As seen, dropping NAFTA countries from the sample does lower the estimated impact - from a $60 \%$ reduction in $\mathrm{AD}$ activity to a $50 \%$ reduction but the estimate remains statistically significant and large.

Second, we drop the EC/EU PTAs. Our concern is that the EU in involved as the "hub" in so many PTAs that its philosophy toward PTAs is the cause of the findings; that is, the results may be more of an EU story that a PTA story. As with NAFTA, we do not see a significant impact on our estimates. 


\section{Alternative Classification of PTA Rules}

In our review of the AD rules in PTAs we found 11 PTAs that had very weak PTA rules. We include information on the identity of these PTAs in Table 1. From what we could ascertain the AD provisions in these PTAs essentially amount to a reaffirmation of WTO AD rules. The fact that the negotiators felt it necessary to include the language in the PTA text might be a signal that $\mathrm{AD}$ was to be discouraged, but we were not able to identify specific stronger language that would indicate that intra-PTA AD cases are more difficult. To be on the safe side, we reclassified these 11 PTAs as having "No Rules” instead of “AD Rules”. We then re-ran our regressions and report the results in Table $9 .^{14}$

The results differ from our benchmark results. While the estimates for "Prohibit" and "AD Rules" are about the same as our benchmark regressions, the estimated impact of "No AD Rules” is much lower. In fact, with this new classification we find essentially the same impact for PTAs with "AD rules" and those with "No AD Rules". If this alternative classification is correct, then our results imply that PTA AD rules are not critical for changing the incidence of AD activity. These results suggest that existence of the PTA deters AD use against member countries. In this case, the PTA conveys political good will on member countries and deters protection. While this result is plausible, we continue to have greater confidence in our original classification. The benchmark results indicate that PTAs with no language do not deter AD use; This means these new estimates are entirely driven by the 11 PTAs who were reclassified. Perhaps the insertion of WTO AD language into these 11 PTAs sends a signal that AD allegations against PTA members are discouraged and, as a result, these 11 PTAs cannot be considered as having no AD rules.

\section{Fixed and Unbalanced Panels}

Our benchmark specifications utilize random effects and are based on balanced panels. We relax both requirements and find our results largely unaffected. We do find that the impact of "No Rules" is changed when we use an unbalanced panel - the point estimate is less than one but it remains statistically insignificant. We take this as another indication that PTAs without rules do not significantly impact the pattern of AD activity.

\footnotetext{
${ }^{14}$ This alternative classification has no impact on the simple "PTA" dummy regressions in Table 8.
} 


\section{Collapse Pre- and Post- Periods (Bertrand, Duflo and Mullainathan)}

In the most standard DiD application one would compares the difference in outcomes after and before the intervention for countries affected by the PTA to the same difference for non-PTA countries. In our application, however, we observe countries for a series of years both before and after the PTA treatment. In an important paper Bertrand, Duflo and Mullainathan (2004) show that ignoring serial correlation may result in inconsistent standard errors. Bertrand, Duflo and Mullainathan suggest collapsing the time series information into a "pre" and "post" period is a conservative approach toward the problem. We follow their advice and the results are presented in Table 10. Two comments on these results are warranted. First, the estimates remain highly significant suggesting that the serial correlation is not driving statistical significance. Second, the point estimate implies an even bigger effect of PTAs than found in Table 3. Given the summary data shown in Table 2 we expected a small point estimate; without the other explanatory variables like GDP and the exchange rate the DiD variable absorbs all change in filing incidence.

\section{Errors with Respect to the Effective Date of the PTA}

In all of the preceding analysis we presume that the economically relevant date is the year of PTA enactment. It is possible that the effective date could be before or after the enactment year. Freund and McLaren (1999) argue that trade patterns change in advance of the official enactment date as firms anticipate the new trading environment. On the other hand, it is also possible that firms and bureaucratic agencies adjust to new rules with a lag. We investigated the sensitivity of our results to the timing and report the results in Figure 3. In this graph we report the DiD parameter for the basic specification (Table 3) and for the DiD parameter for "AD Rules” (Table 4). For each case we re-classified the effective date of each PTA from the year of enactment to +/- 3 years. If a PTA came into force in 1994 our benchmark regression would treat 1994 as the effective year $(\mathrm{t}=0)$. In these robustness runs we perform six alternative regressions, one where we treat $1993(\mathrm{t}=-1)$ as the effective year, one where we treat $1992(\mathrm{t}=-2)$ as the effective year, one where we treat $1995(\mathrm{t}=+1)$ as the effective year, etc.

The results are depicted in the graph. A solid marker denotes statistical significance while a hollow marker indicates the parameter estimate is statistically insignificant. The results indicate that as long as the effective date is within $+/$ - one year of the actual year of enactment 
our results are essentially unaffected. The parameter estimates do not change very much and the estimates are statistically significant. If, however, the economically effective date is more than one year from the official enactment date then we lose significance.

\section{Concluding Comments}

This paper presents new evidence that PTAs significantly alter the pattern of protection. Economists have long known that PTAs grant preferential tariffs to members; this paper provides evidence that the playing field is further tilted because of how PTA members use AD protection. Said differently, PTAs discriminate in both direct and indirect ways. Direct discrimination stems from preferential tariffs and indirect discrimination follows from the altered pattern of AD activity

One key implication of this work is that in a world teeming with PTAs, there is greater need for stronger multilateral disciplines on trade remedies. It appears that Bhagwati and Panagariya's fear of increased discrimination against non-members was well founded. To the extent that PTAs adopt special or additional rules on trade remedy actions against members’ trade, they can effectively increase the level of discrimination against non-members. This increase in discrimination can occur when PTA members abolish trade remedy actions against the trade of PTA members but not against non-members' trade. It could also occur when PTA members adopt rules that strengthen disciplines on trade remedy actions against the trade of PTA members but not against the trade of non-members.

At first blush moves to strengthen disciplines on trade remedy actions against PTA partners or to abolish trade remedy actions against PTA partners appear good for trade. However, the welfare effects are ambiguous. Such rules may simply lead to intra-regional imports substituting for cheaper sources of imports from non-members, i.e., trade diversion. Since PTAs thrust us into the world of the second best, actions that look like they will lead to an increase in economic efficiency may achieve exactly the opposite effect. 


\section{Bibliography}

Baldwin, Robert E. and Jeffrey W. Steagall. (1994). “An Analysis of ITC Decisions in Antidumping, Countervailing Duty and Safeguard Cases,” Review of World Economics, 130(2): 290-308.

Bertrand, Marianne, Esther Duflo and Sendhil Mullainathan (2004). "How Much Should We Trust Differences-in-Differences Estimates?” Quarterly Journal of Economics, 119(1), 249-75.

Bhagwati, Jagdish. 1992. “Regionalism versus multilateralism,” World Economy 15(5): 535-56.

Bhagwati, Jagdish. 1993. "Regionalism and Multilateralism: An Overview.” in de Melo, Jaime and Arvind Panagariya (eds.) New Dimensions in Regional Integration. Cambridge: Cambridge University Press.

Bhagwati, Jagdish, and Arvind Panagariya. (Eds.). 1996. The Economics of Preferential Trade Agreements. Washington, DC: AEI Press.

Blonigen, Bruce A. (2005), “The Effects of NAFTA on Antidumping and Countervailing Duty Activity,” World Bank Economic Review, 19(3): 407-24.

Blonigen, Bruce A. (2006) "Evolving Discretionary Practices of U.S. Antidumping Activity." Canadian Journal of Economics, 39(3): 874-900.

Blonigen, Bruce A. and Chad P. Bown (2003) “Antidumping and Retaliation Threats,” Journal of International Economics 60(2): 249-273.

Blonigen, Bruce A. and Thomas J. Prusa (2003), “Antidumping” in Handbook of International Economics, edited by E. Kwan Choi and James Harrigan, (Malden, MA, Blackwell Publishing), 251-84.

Dee, Philippa (2008) “Multinational corporations and Pacific regionalism,” in J. Palacios (ed.), Multinational Corporations and the Emerging Network Economy in Asia and the Pacific, Routledge, London and New York, 232-66.

DeVault, James M. (October 1993). "Economics and the International Trade Commission,” Southern Economic Journal, 60(2): 463-478.

Eicher, Theo, Christian Henn and Chris Papageorgiou (2010) “Trade Creation and Diversion Revisited: Accounting for Model Uncertainty and Natural Trading Partner Effects, forthcoming Journal of Applied Econometrics.

Estevadeordal, Antoni, Kati Suominen and Robert Teh, editors. (2009) Regional Rules in the Global Trading System, (Cambridge: Cambridge University Press). 
Feinberg, Robert M. (1989). "Exchange Rates and Unfair Trade,” Review of Economics and Statistics, 71(4): 704-7.

Feinberg, Robert M. and Barry T. Hirsch. (1989). "Industry Rent Seeking and the Filing of 'Unfair Trade' Complaints," International Journal of Industrial Organization, 7(3): 325340.

Finger, J. M., H. Keith Hall, and Douglas R. Nelson. (June 1982) "The Political Economy of Administered Protection,” American Economic Review, 72(3): 452-66.

Freund, Caroline L. and McLaren, John (June 1999). "On the Dynamics of Trade Diversion: Evidence from Four Trade Blocs,” World Bank International Finance Working Paper No. 637.

Freund, Caroline L. (2010) “Third Country Effects of Regional Trade Agreements,” forthcoming The World Economy.

Gallaway, Michael P., Bruce A. Blonigen, and Joseph E. Flynn. (1999) "Welfare Costs of U.S. Antidumping and Countervailing Duty Laws.” Journal of International Economics 49(2): 211-44.

Horlick, Gary and Edwin Vermulst. (2005) "The 10 Major Problems with the Anti-Dumping Instrument: An Attempt at Synthesis”, Journal of World Trade, 39(1), 67-74.

Irwin, Douglas (2005) “The Rise of U.S. Antidumping Activity in Historical Perspective," The World Economy 28(5), 651-668.

Jones, Kent. (April 2000). "Does NAFTA Chapter 19 Make a Difference? Dispute Settlement and the Incentive Structure of U.S./Canada Unfair Trade Petitions," Contemporary Economic Policy, 18(2): 145-158.

Knetter, Michael M. and Thomas J. Prusa. (2003). "Macroeconomic Factors and Antidumping Filings: Evidence from Four Countries,” Journal of International Economics 61(1), 1-17.

Lindsey, Brink and Dan Ikenson, (2002) "Antidumping 101: The Devilish Details of 'Unfair Trade’ Law,” CATO Institute Center for Trade Policy Studies Working Paper No. 20.

Mastel, G. (1998), Antidumping Laws and the US Economy (Armonk, NY: M.E. Sharpe).

Messerlin, Patrick A., Measuring the Costs of Protection in Europe. Washington DC: Institute for International Economics, 2001.

Miranda, Jorge, Raul A. Torres, Raul and Mario Ruiz (1998) "The International Use of Antidumping: 1987-1997.” Journal of World Trade 32(5): 5-71.

Moore, Michael O. (July 1992) "Rules or Politics? An Empirical Analysis of ITC Anti-dumping Decisions,” Economic Inquiry, 30(3): 449-466. 
Moore, Michael O. and Alan Fox (2010) "Why Don't Foreign Firms Cooperate in U.S. Antidumping Investigations? An Empirical Analysis,” Review of World Economics 145(4), 597-613.

Prusa, Thomas J., (2000) “On the Spread and Impact of Antidumping,” Canadian Journal of Economics 34(3), 591-611.

Prusa, Thomas J. (2005), “Anti-dumping: A Growing Problem in International Trade’, The World Economy, 28(5) 683-700.

Staiger, R. W. and F. A. Wolak (1994), "Measuring Industry Specific Protection: Antidumping in the United States," Brookings Papers on Economic Activity: Microeconomics, 51-118.

Stevenson, Cliff (2009) Globe Trade Protection Report 2009, www.antidumpingpublishing.com.

Teh, Robert, Michele Budetta, and Thomas J. Prusa, (2009) “Trade remedy provisions in regional trade agreements," in Regional Rules in the Global Trading System, edited by Antoni Estevadeordal, Kati Suominen, and Robert Teh, (Cambridge: Cambridge University Press), Chapter 4, pp. 166-249. 
Figure 1: Intra-PTA AD Filings

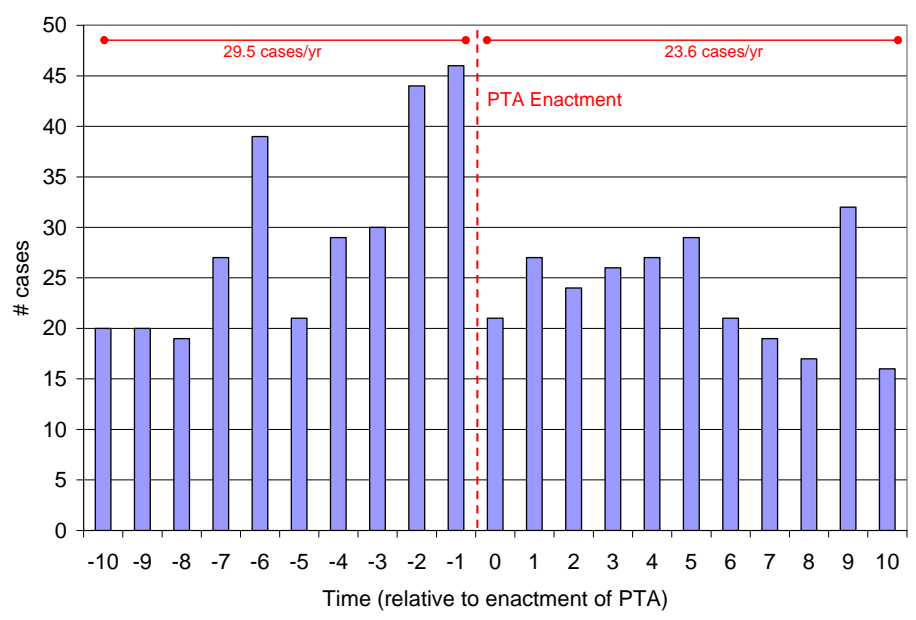

(a) unbalanced sample

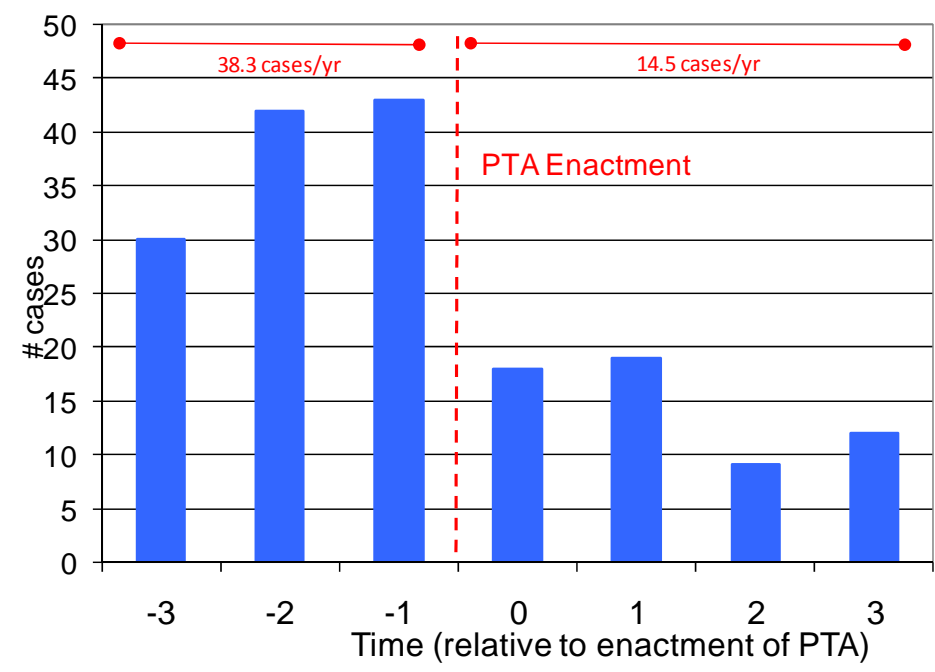

(b) balanced sample, $+/-3$ years

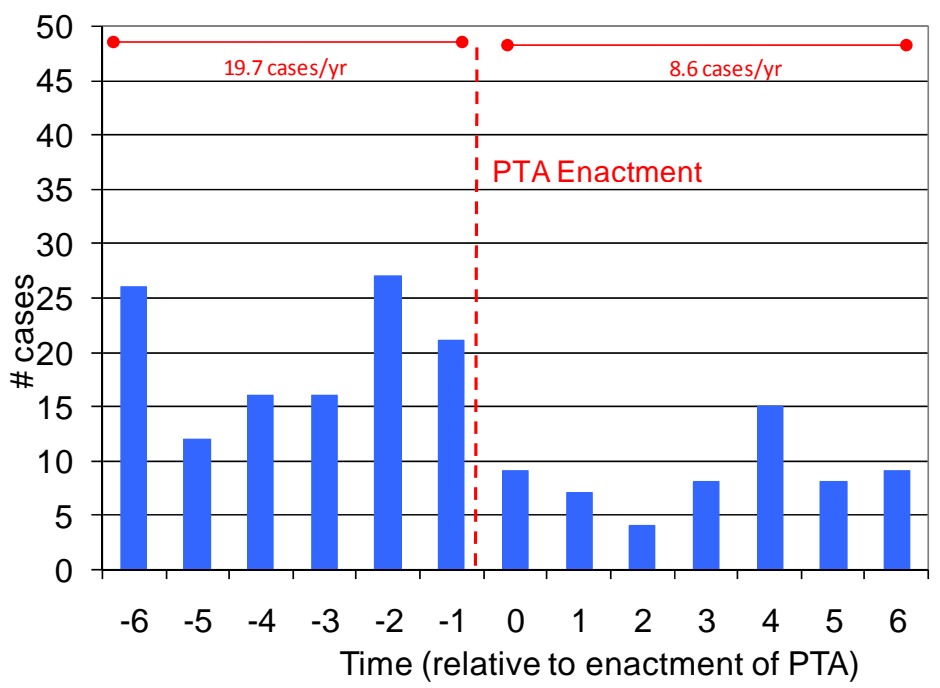

(c) balanced sample, $+/-6$ years 
Figure 2: AD Filings by NAFTA Members

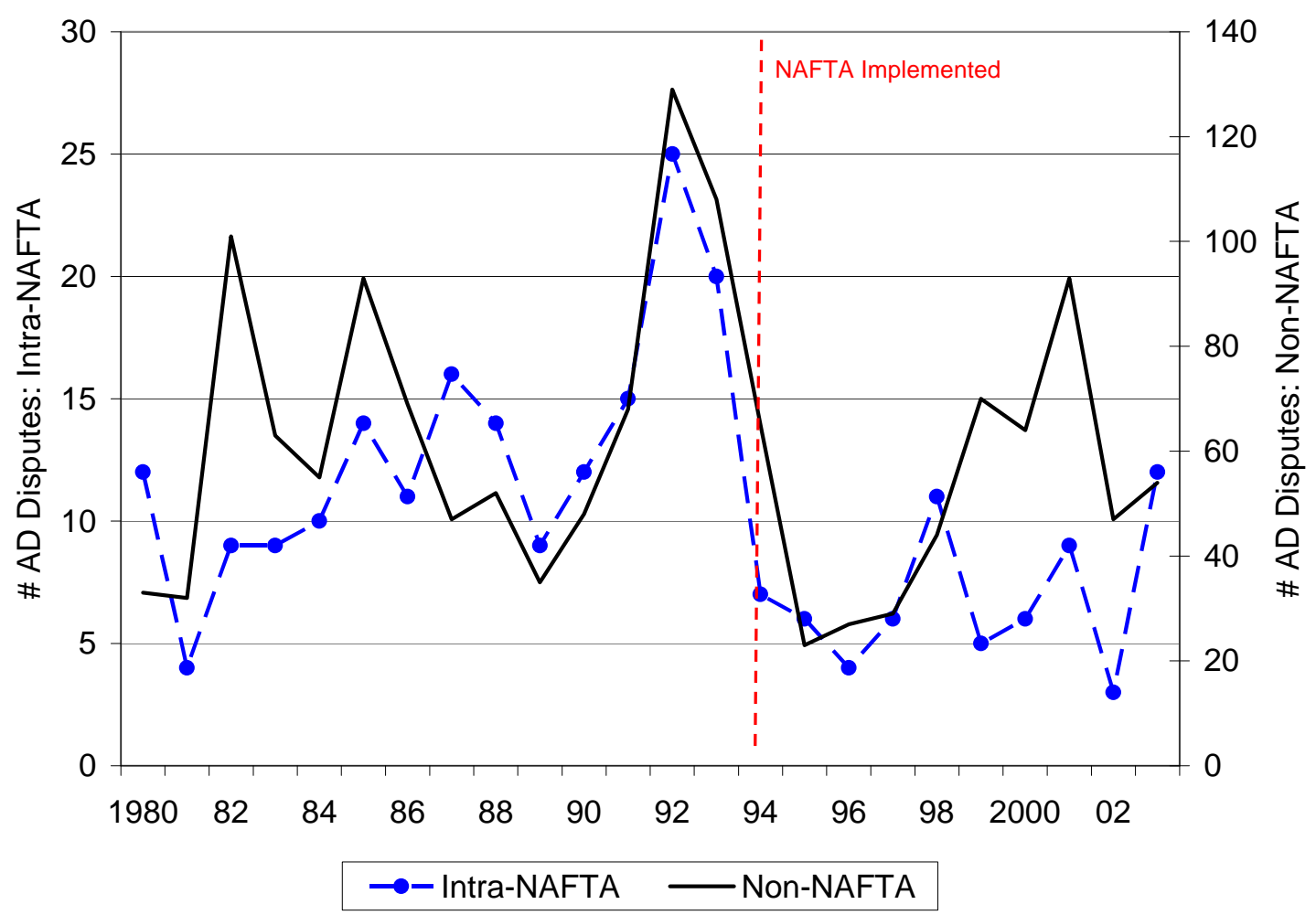

Figure 3: Robustness to Errors in Effective Date of PTA

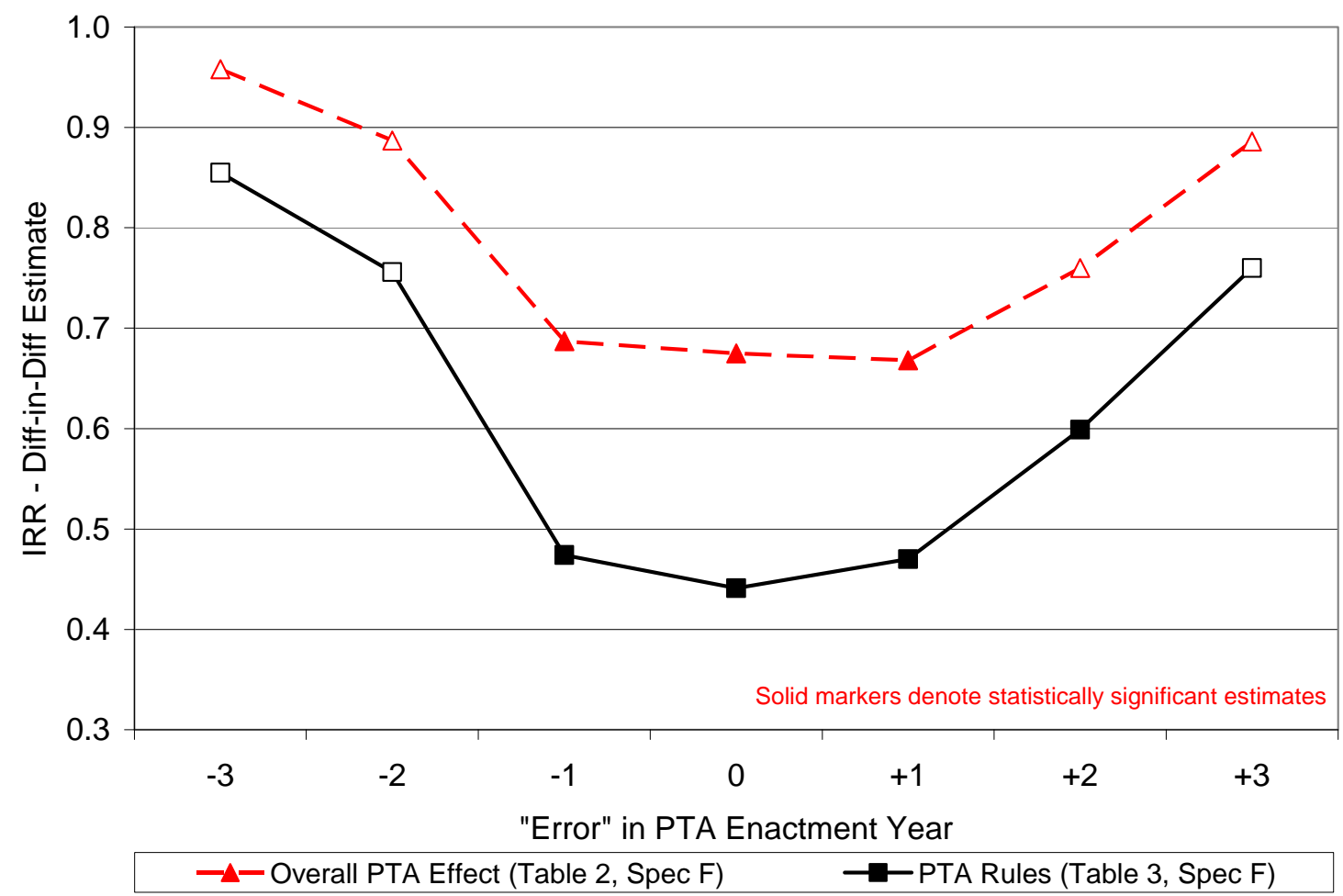


Table 1: PTAs and AD rules

\begin{tabular}{|c|c|c|}
\hline PTA Name & $\begin{array}{c}\text { PTA } \\
\text { AD Rules }\end{array}$ & $\begin{array}{l}\text { Start } \\
\text { Year }\end{array}$ \\
\hline AFTA & No & 1992 \\
\hline Aladi & No & 1981 \\
\hline $\begin{array}{l}\text { Canada- } \\
\text { Costa Rica* }\end{array}$ & Rules & 2002 \\
\hline Andean Commty ${ }^{\dagger}$ & Rules & $1999^{\ddagger}$ \\
\hline Australia-Singapre & Rules & 2003 \\
\hline Australia-Thailand & Rules & 2005 \\
\hline Australia-US & No & 2005 \\
\hline CACM & Rules & 1961 \\
\hline Canada-Chile & Prohibited & 1997 \\
\hline Canada-I srael* & No & 1997 \\
\hline Caricom & Rules & 1973 \\
\hline CEFTA & Rules & 1993 \\
\hline CEMAC* & No & 1999 \\
\hline CER & Prohibited & $1990^{\S}$ \\
\hline China-Hong Kong ${ }^{*}$ & Prohibited & 2004 \\
\hline China-Macao* & Prohibited & 2004 \\
\hline COMESA & Rules & 1994 \\
\hline EC-Algeria & Rules & 2005 \\
\hline EC-Andorra* & No & 1991 \\
\hline EC-Bulgaria & Rules & 1993 \\
\hline EC-Chile & Rules $^{* *}$ & 2003 \\
\hline EC-Croatia* & Rules & 2002 \\
\hline EC-Egypt & Rules $^{* *}$ & 2004 \\
\hline EC-Faroe I slands* & Rules & 1997 \\
\hline EC-Macedonia* & Rules & 2001 \\
\hline EC-I srael & Rules & 2000 \\
\hline EC-J ordan* & Rules & 2002 \\
\hline EC-Lebanon* & Rules $^{* *}$ & 2003 \\
\hline EC-Mexico & Rules $^{* *}$ & 2000 \\
\hline EC-Morocco* & Rules & 2000 \\
\hline EC-OCT* & No & 1971 \\
\hline EC-Pal Authority* & Rules $^{* *}$ & 1997 \\
\hline EC-Romania & Rules & 1993 \\
\hline EC-South Africa & Rules $^{* *}$ & 2000 \\
\hline EC-Switz. \& Liech. & Rules & 1973 \\
\hline EC-Syria* & Rules & 1977 \\
\hline EC-Tunisia & Rules & 1998 \\
\hline EC-Turkey & Rules & 1996 \\
\hline EEA & Prohibited & $1994^{\dagger \dagger}$ \\
\hline EFTA* & Prohibited & $2001^{\text {f† }}$ \\
\hline EFTA-Bulgaria* & Rules & 1993 \\
\hline EFTA-Chile ${ }^{*}$ & Prohibited & 2004 \\
\hline EFTA-Croatia* & Rules & 2002 \\
\hline EFTA-FYROM* & Rules & 2001 \\
\hline EFTA-I srael* & Rules & 1993 \\
\hline EFTA-J ordan* & Rules & 2002 \\
\hline EFTA-Morocco* & Rules & 1999 \\
\hline EFTA-Pal Auth* & Rules & 1999 \\
\hline EFTA-Romania* & Rules & 1993 \\
\hline
\end{tabular}

\begin{tabular}{|c|c|c|}
\hline PTA Name & $\begin{array}{c}\text { PTA } \\
\text { AD Rules }\end{array}$ & $\begin{array}{l}\text { Start } \\
\text { Year }\end{array}$ \\
\hline $\begin{array}{l}\text { EFTA- } \\
\text { Singapore* }\end{array}$ & Prohibited & 2003 \\
\hline EFTA-Tunisia* & Rules & 2005 \\
\hline EFTA-Turkey* & Rules & 1992 \\
\hline EC/ EU & Prohibited & 1958 \\
\hline GCC & No & 2003 \\
\hline Group of $3^{\dagger}$ & Rules & 1994 \\
\hline $\begin{array}{l}\text { Japan- } \\
\text { Singapore* }\end{array}$ & No & 2002 \\
\hline Korea-Chile & Rules $^{* *}$ & 2004 \\
\hline Mercosur & Rules & 1991 \\
\hline $\begin{array}{l}\text { Mexico- } \\
\text { Northern } \\
\text { Triangle }\end{array}$ & Rules & 2001 \\
\hline Mexico-Chile & No & 1999 \\
\hline Mexico-EFTA* & Rules & 2001 \\
\hline Mexico-I srael & Rules $^{* *}$ & 2000 \\
\hline Mexico-J apan & No & 2005 \\
\hline $\begin{array}{l}\text { Mexico- } \\
\text { Nicaragua* }\end{array}$ & Rules & 1998 \\
\hline $\begin{array}{l}\text { Mexico- } \\
\text { Uruguay }{ }^{*},\end{array}$ & Rules & 2003 \\
\hline NAFTA & Rules & 1994 \\
\hline $\begin{array}{l}\text { New Zealand- } \\
\text { Singapore }\end{array}$ & Rules $^{* *}$ & 2001 \\
\hline SADC & Rules $^{* *}$ & 2000 \\
\hline SAFTA & Rules & 1995 \\
\hline SPARTECA & Rules & 1981 \\
\hline Turkey-I srael & Rules & 1997 \\
\hline Turkey-Rom. & Rules & 1998 \\
\hline UEMOA* & Rules & 2000 \\
\hline US-Bahrain* & No & 2006 \\
\hline $\begin{array}{l}\text { US-CAFTA } \\
\text { Dom. Rep. }\end{array}$ & Rules $^{* *}$ & 2006 \\
\hline US-Chile & No & 2004 \\
\hline US-I srael & No & 1985 \\
\hline US-J ordan* & No & 2001 \\
\hline US-Morocco* & No & 2006 \\
\hline US-Singapore & No & 2004 \\
\hline
\end{tabular}

Notes:

${ }^{*}$ No AD Activity

${ }^{\dagger}$ Formal notification not given to GATT/WTO (as of 04/30/2010)

₹ Enacted in 1969; AD provisions added in 1999

$\S$ Enacted in 1983; AD prohibition added in 1990

${ }^{* *}$ Weak AD Rules

${ }^{++}$AD abolished among the parties except for agricultural and fishery products.

抹 Enacted in 1960; AD prohibition added in 2001 
Table 2: AD Activity by PTA Status

\begin{tabular}{cccc} 
& \multicolumn{2}{c}{ Target } \\
\cline { 2 - 3 } & $\begin{array}{c}\text { Non-PTA } \\
\text { Country }\end{array}$ & & $\begin{array}{c}\text { PTA } \\
\text { Country }\end{array}$ \\
\cline { 2 - 2 } Pre-PTA & $\begin{array}{c}506 \\
(58 \%)\end{array}$ & & $\begin{array}{c}370 \\
\end{array}$ \\
Post-PTA & $3,554)$ & & 375 \\
& $(90 \%)$ & & $(10 \%)$
\end{tabular}


Table 3: Bilateral AD Filings (balanced panel)

\begin{tabular}{|c|c|c|c|c|c|c|}
\hline & A & B & C & D & $E$ & $F$ \\
\hline \multirow[t]{2}{*}{ Post PTA Inception } & $1.139 * \star$ & $1.271^{\star \star \star}$ & $1.315^{\star \star *}$ & $1.139 * *$ & $1.270^{\star \star *}$ & $1.315^{\star \star \star}$ \\
\hline & [0.041] & [0.003] & {$[0.001]$} & {$[0.041]$} & [0.003] & {$[0.001]$} \\
\hline \multirow[t]{2}{*}{ PTA } & $1.804^{\star \star \star}$ & $2.055^{\star \star \star}$ & $1.860^{\star \star \star}$ & $1.846^{\star \star \star}$ & $1.987^{\star \star \star}$ & $1.678^{\star * *}$ \\
\hline & {$[0.000]$} & {$[0.000]$} & {$[0.000]$} & {$[0.000]$} & {$[0.000]$} & [0.002] \\
\hline \multirow[t]{2}{*}{ PTA x Post } & $0.421^{\star \star *}$ & $0.434^{\star * \star}$ & $0.418^{* \star *}$ & $0.398^{\star \star \star}$ & $0.534^{* \star *}$ & $0.675^{\star}$ \\
\hline & {$[0.000]$} & {$[0.000]$} & {$[0.000]$} & {$[0.000]$} & [0.008] & {$[0.081]$} \\
\hline \multirow[t]{2}{*}{ Ln Real ER, t-1 } & & $1.473^{\star \star \star}$ & $1.378^{\star \star \star}$ & & $1.484^{\star \star \star}$ & $1.393^{\star * \star}$ \\
\hline & & {$[0.000]$} & {$[0.000]$} & & {$[0.000]$} & [0.000] \\
\hline \multirow[t]{2}{*}{ Ln Importing GDP, t-3 } & & $0.530 * \star \star$ & $0.515^{\star \star \star}$ & & $0.530 * \star \star$ & $0.516^{\star * *}$ \\
\hline & & {$[0.000]$} & {$[0.000]$} & & {$[0.000]$} & [0.000] \\
\hline \multirow[t]{2}{*}{ Ln Exporting GDP, t-3 } & & $1.435^{\star \star \star}$ & 1.103 & & $1.437^{\star \star \star}$ & 1.097 \\
\hline & & {$[0.000]$} & [0.301] & & {$[0.000]$} & [0.331] \\
\hline \multirow[t]{2}{*}{ Ln Trade Value, t-1 } & & & $1.295^{\star \star *}$ & & & $1.306^{\star * *}$ \\
\hline & & & {$[0.000]$} & & & [0.000] \\
\hline \multirow[t]{2}{*}{ WTO PTA Investment Mapping Index } & & & & 1.092 & 0.669 & $0.382^{* * *}$ \\
\hline & & & & [0.799] & [0.265] & [0.006] \\
\hline Observations & 10,927 & 8,550 & 8,330 & 10,872 & 8,512 & 8,292 \\
\hline Number of Bilateral Country Pairs & 762 & 605 & 598 & 760 & 603 & 596 \\
\hline Log LikeLihood & -8226.5 & -6551.3 & -6323.7 & -8202.6 & -6541.1 & -6309.0 \\
\hline \multicolumn{7}{|c|}{ Implied Change in AD Activity by End of Sample } \\
\hline Intra-PTA Effect Only & $-17.1 \%$ & $-19.9 \%$ & $-20.1 \%$ & $-17.9 \%$ & $-13.0 \%$ & $-6.6 \%$ \\
\hline Intra-PTA Effect \& Diversion & $-7.4 \%$ & $-3.2 \%$ & $-1.5 \%$ & $-8.2 \%$ & $3.7 \%$ & $12.1 \%$ \\
\hline
\end{tabular}

Coefficients reported as incidence-rate ratios, $\mathrm{p}$ values in brackets

* significant at 10\%; ** significant at 5\%; *** significant at $1 \%$

Coefficients reported as incidence-rate ratios 
Table 4: Bilateral AD Filings by type of PTA Rules (balanced panel)

\begin{tabular}{|c|c|c|c|c|c|c|}
\hline & A & B & C & D & $E$ & $F$ \\
\hline \multirow[t]{2}{*}{ Post PTA Inception } & $1.139 * *$ & $1.271^{\star \star *}$ & $1.317^{\star \star \star}$ & $1.139 * *$ & $1.272^{\star \star \star}$ & $1.320^{* * *}$ \\
\hline & [0.041] & [0.003] & {$[0.001]$} & [0.041] & [0.003] & [0.001] \\
\hline \multirow[t]{2}{*}{ PTA - AD Prohibited } & 0.327 & $0.302^{*}$ & $0.236^{\star \star}$ & 0.327 & $0.302^{*}$ & $0.235^{\star \star}$ \\
\hline & {$[0.105]$} & [0.090] & {$[0.034]$} & {$[0.105]$} & {$[0.090]$} & [0.033] \\
\hline \multirow[t]{2}{*}{ PTA - AD Rules } & $1.952^{* * *}$ & $2.181^{\star \star \star}$ & $1.857^{* * *}$ & $2.008^{* * *}$ & $2.194^{\star \star \star}$ & $1.840 * \star *$ \\
\hline & {$[0.000]$} & {$[0.000]$} & {$[0.000]$} & {$[0.000]$} & {$[0.000]$} & [0.000] \\
\hline \multirow[t]{2}{*}{ PTA - AD No Rules } & 0.761 & 0.894 & 0.908 & 0.769 & 0.896 & 0.909 \\
\hline & [0.727] & [0.886] & [0.902] & {$[0.737]$} & [0.890] & [0.902] \\
\hline \multirow[t]{2}{*}{ PTA - AD Prohibited x Post } & 0 & 0 & 0 & 0 & 0 & 0 \\
\hline & [0.997] & [0.995] & [0.995] & {$[0.997]$} & [0.997] & [0.996] \\
\hline \multirow[t]{2}{*}{ PTA - AD Rules x Post } & $0.392^{* * *}$ & $0.393^{\star * *}$ & $0.361^{* * *}$ & $0.299 * \star *$ & $0.391^{\star \star *}$ & $0.441^{\star \star *}$ \\
\hline & {$[0.000]$} & {$[0.000]$} & {$[0.000]$} & {$[0.000]$} & {$[0.001]$} & [0.003] \\
\hline \multirow[t]{2}{*}{ PTA - AD No Rules x Post } & 1.156 & 1.335 & 1.352 & 1.058 & 1.323 & 1.437 \\
\hline & [0.853] & {$[0.713]$} & {$[0.698]$} & [0.943] & {$[0.724]$} & [0.641] \\
\hline \multirow[t]{2}{*}{ Ln Real ER, t-1 } & & $1.493^{\star * *}$ & $1.398^{* \star *}$ & & $1.493^{\star \star *}$ & $1.401^{* * *}$ \\
\hline & & {$[0.000]$} & {$[0.000]$} & & {$[0.000]$} & [0.000] \\
\hline \multirow[t]{2}{*}{ Ln Importing GDP, t-3 } & & $0.532^{* * *}$ & $0.519 * * *$ & & $0.530 * * *$ & $0.516^{\star * *}$ \\
\hline & & {$[0.000]$} & {$[0.000]$} & & {$[0.000]$} & {$[0.000]$} \\
\hline \multirow[t]{2}{*}{ Ln Exporting GDP, t-3 } & & $1.433^{\star \star \star}$ & 1.095 & & $1.432^{\star \star *}$ & 1.091 \\
\hline & & {$[0.000]$} & {$[0.341]$} & & {$[0.000]$} & [0.359] \\
\hline \multirow[t]{2}{*}{ Ln Trade Value, t-1 } & & & $1.306^{\star * \star}$ & & & $1.310 * \star \star$ \\
\hline & & & {$[0.000]$} & & & [0.000] \\
\hline \multirow[t]{2}{*}{ WTO PTA Investment Mapping Index } & & & & 1.672 & 1.056 & 0.708 \\
\hline & & & & [0.207] & [0.899] & [0.400] \\
\hline Observations & 10,927 & 8,550 & 8,330 & 10,872 & 8,512 & 8,292 \\
\hline Number of Bilateral Country Pairs & 762 & 605 & 598 & 760 & 603 & 596 \\
\hline Log LikeLihood & -8216.0 & -6538.6 & -6305.0 & -8191.4 & -6529.1 & -6294.0 \\
\hline \multicolumn{7}{|c|}{ Implied Change in AD Activity by End of Sample } \\
\hline Intra-PTA Effect Only & $-12.1 \%$ & $-13.5 \%$ & $-13.9 \%$ & $-17.2 \%$ & $-12.9 \%$ & $-9.1 \%$ \\
\hline Intra-PTA Effect \& Diversion & $-2.4 \%$ & $3.2 \%$ & $4.8 \%$ & $-7.5 \%$ & $3.9 \%$ & $9.9 \%$ \\
\hline
\end{tabular}

Coefficients reported as incidence-rate ratios, $\mathrm{p}$ values in brackets

* significant at 10\%; ** significant at 5\%; *** significant at $1 \%$

Coefficients reported as incidence-rate ratios 
Table 5: Robustness check using OECD FDI data

\begin{tabular}{|c|c|c|c|c|c|c|}
\hline & $\mathbf{G}$ & $\mathrm{H}$ & 1 & $\mathbf{J}$ & $\mathrm{K}$ & L \\
\hline \multirow[t]{2}{*}{ Post PTA Inception } & 1.142 & 1.145 & 1.096 & 1.048 & 1.146 & 1.126 \\
\hline & {$[0.16]$} & {$[0.15]$} & {$[0.36]$} & {$[0.66]$} & {$[0.17]$} & {$[0.27]$} \\
\hline \multirow[t]{2}{*}{ PTA - AD Prohibited } & $0.221^{\star *}$ & $0.221^{\star \star}$ & $0.216^{\star \star}$ & $0.190^{* *}$ & $0.202^{\star \star}$ & $0.202^{\star \star}$ \\
\hline & [0.033] & {$[0.032]$} & [0.031] & {$[0.021]$} & {$[0.024]$} & [0.024] \\
\hline \multirow[t]{2}{*}{ PTA - AD Rules } & $1.527^{*}$ & $1.566^{*}$ & $1.592^{*}$ & 1.236 & $1.493^{*}$ & 1.415 \\
\hline & [0.072] & [0.059] & [0.059] & {$[0.40]$} & [0.093] & {$[0.15]$} \\
\hline \multirow[t]{2}{*}{ PTA - AD No Rules } & 0.735 & 0.737 & 0.858 & 1.252 & 0.776 & 1.216 \\
\hline & [0.79] & {$[0.79]$} & [0.89] & [0.85] & [0.83] & {$[0.87]$} \\
\hline \multirow[t]{2}{*}{ PTA - AD Prohibited x Post } & 0 & 0 & 0 & 0 & 0 & 0 \\
\hline & [1.00] & [1.00] & [1.00] & {$[0.99]$} & [1.00] & {$[1.00]$} \\
\hline \multirow[t]{2}{*}{ PTA - AD Rules x Post } & $0.427^{\star \star \star}$ & $0.473^{*}$ & $0.434^{* * *}$ & $0.512^{\star \star *}$ & $0.399 * \star *$ & $0.421^{\star * *}$ \\
\hline & [0.000] & [0.062] & [0.000] & [0.001] & [0.000] & {$[0.000]$} \\
\hline \multirow[t]{2}{*}{ PTA - AD No Rules x Post } & 1.754 & 1.768 & 1.542 & 0.958 & 1.532 & 1 \\
\hline & [0.61] & [0.61] & [0.70] & [0.97] & [0.70] & [1.00] \\
\hline \multirow[t]{2}{*}{ Ln Real ER, t-1 } & $2.241^{\star \star \star}$ & $2.241^{\star * *}$ & $2.127^{\star * \star}$ & $2.103^{* \star *}$ & $2.201^{* * *}$ & $2.166^{\star * *}$ \\
\hline & {$[0.000]$} & {$[0.000]$} & {$[0.000]$} & {$[0.000]$} & {$[0.000]$} & [0.000] \\
\hline \multirow[t]{2}{*}{ Ln Importing GDP, t-3 } & $0.282^{\star \star *}$ & $0.281^{\star \star \star}$ & $0.273^{* \star *}$ & $0.417^{* * *}$ & $0.289 * \star \star$ & $0.338^{* * *}$ \\
\hline & {$[0.000]$} & {$[0.000]$} & {$[0.000]$} & {$[0.000]$} & {$[0.000]$} & [0.000] \\
\hline \multirow[t]{2}{*}{ Ln Exporting GDP, t-3 } & $1.241^{*}$ & $1.238^{\star}$ & 1.192 & $1.256^{*}$ & $1.253^{*}$ & 1.164 \\
\hline & {$[0.062]$} & {$[0.064]$} & {$[0.15]$} & {$[0.077]$} & [0.061] & {$[0.22]$} \\
\hline \multirow[t]{2}{*}{ Ln Trade Value, t-1 } & $1.365^{\star \star \star}$ & $1.367^{\star \star \star}$ & $1.369 * \star *$ & $1.405^{\star \star *}$ & $1.451^{\star \star \star}$ & $1.425^{\star \star \star}$ \\
\hline & {$[0.000]$} & {$[0.000]$} & {$[0.000]$} & {$[0.000]$} & {$[0.000]$} & [0.000] \\
\hline \multirow[t]{2}{*}{ WTO PTA Investment Mapping Index } & & 0.858 & & & & \\
\hline & & [0.81] & & & & \\
\hline \multirow[t]{2}{*}{ Ln FDI Outflow, lag 1} & & & 1.002 & & & \\
\hline & & & {$[0.88]$} & & & \\
\hline \multirow[t]{2}{*}{ Ln FDI Outflow, lag 2} & & & & $0.960 * \star \star$ & & \\
\hline & & & & [0.0005] & & \\
\hline \multirow[t]{2}{*}{ Ln FDI Outward Position, lag 1} & & & & & $0.959 * * *$ & \\
\hline & & & & & [0.0003] & \\
\hline \multirow[t]{2}{*}{ Ln FDI Outward Position, lag 2} & & & & & & $0.975^{\star \star}$ \\
\hline & & & & & & [0.042] \\
\hline Observations & 5,177 & 5,148 & 4,782 & 4,669 & 5,004 & 4,859 \\
\hline Number of Bilateral Country Pairs & 291 & 290 & 290 & 290 & 291 & 291 \\
\hline Log LikeLihood & -4040.0 & -4034.0 & -3751.0 & -3574.0 & -3914.0 & -3724.0 \\
\hline
\end{tabular}

Coefficients reported as incidence-rate ratios, $p$ values in brackets

* significant at 10\%; ** significant at 5\%; *** significant at $1 \%$

Coefficients reported as incidence-rate ratios 
Table 6: Implied Change in AD Disputes Without PTAs (Table 4, Specification F)

(1)

Time Period 1980-84 1985-89 1990-94 1995-99 2000AD Provisions Intra-PTA \&

$\frac{\text { AD Provisions }}{\text { Intra-PTA \& }}$
Intra-PTA Only

$-3.2 \%$

$-1.3 \%$

$-1.5 \%$

$-6.2 \%$

$-9.1 \%$
(2)

(3)

(4)

AD \& Investment Provisions Intra-PTA \& Intra-PTA Only Diversion

$6.6 \%$
$15.1 \%$
$14.2 \%$
$12.8 \%$
$9.9 \%$

$6.4 \%$

$14.8 \%$

$13.4 \%$

$-2.3 \%$

$10.4 \%$

$-12.8 \%$

$6.2 \%$ 


\section{Table 7: Difference Estimates}

\begin{tabular}{lcccccc}
\hline & A & B & C & D & E & F \\
\hline Post PTA Inception & & & & & & \\
Intra-PTA & $0.455^{\star \star \star}$ & $0.556^{\star \star \star}$ & $0.513^{\star \star \star}$ & $0.459^{\star \star \star}$ & $0.604^{\star \star}$ & 0.81 \\
Non PTA Members & $1.140^{\star \star}$ & $1.255^{\star \star \star}$ & $1.313^{\star \star \star}$ & $1.140^{\star \star}$ & $1.255^{\star \star \star}$ & $1.313^{\star \star \star}$
\end{tabular}

\begin{tabular}{lccc}
\hline & Rules & No Rules & Prohibited \\
\hline Post PTA Inception, by PTA Type & & & \\
Intra-PTA & $0.434^{\star \star \star}$ & 1.211 & 0 \\
Non PTA Members & $1.158^{\star \star}$ & $1.257^{\star}$ & $0.649^{\star \star \star}$
\end{tabular}

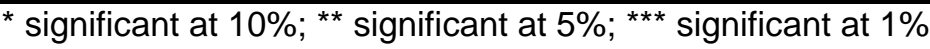

Same specifications as in Table 3 but only the PTA effect coefficient is reported

Coefficients reported as incidence-rate ratios
} 
Table 8: Robustness Checks

\begin{tabular}{|c|c|c|c|c|c|c|}
\hline & $\bar{A}$ & B & C & D & $E$ & $\mathbf{F}$ \\
\hline \multicolumn{7}{|c|}{ Benchmark (Table 3) } \\
\hline PTA $x$ Post & $0.421^{\star \star \star}$ & $0.434^{\star \star \star}$ & $0.418^{\star \star \star}$ & $0.398^{\star \star \star}$ & $0.534^{\star \star \star}$ & $0.675^{\star}$ \\
\hline \multicolumn{7}{|l|}{ Year Dummies } \\
\hline PTA $x$ Post & $0.392^{\star \star \star}$ & $0.404^{\star * *}$ & $0.392^{\star \star \star}$ & $0.356^{\star \star \star}$ & $0.469 * \star \star$ & $0.599 * *$ \\
\hline \multicolumn{7}{|c|}{ Control for Uruguay Round } \\
\hline $\begin{array}{c}\text { PTA } \times \text { Post } \\
\text { Control for BITS }\end{array}$ & $0.417^{* * *}$ & $0.448^{* * *}$ & $0.444^{\star * \star}$ & $0.380^{* * *}$ & $0.529 * * *$ & $0.686^{*}$ \\
\hline PTA $x$ Post & $0.421^{\star \star \star}$ & $0.424^{\star \star \star}$ & $0.415^{\star \star \star}$ & $0.401^{\star \star *}$ & $0.524^{\star \star \star}$ & $0.668^{*}$ \\
\hline \multicolumn{7}{|l|}{ Drop PRC } \\
\hline PTA x Post & $0.441^{\star \star \star}$ & $0.443^{\star \star \star}$ & $0.424^{\star \star \star}$ & $0.417^{\star \star \star}$ & $0.547^{\star \star \star}$ & $0.681^{*}$ \\
\hline \multicolumn{7}{|l|}{ Drop NAFTA } \\
\hline PTA x Post & 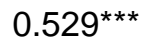 & $0.575^{\star \star \star}$ & $0.585^{\star \star \star}$ & $0.606^{\star \star}$ & 0.804 & 0.839 \\
\hline \multicolumn{7}{|c|}{ Drop EC/EU PTAs } \\
\hline $\begin{array}{l}\text { PTA x Post } \\
\text { Fixed Effects }\end{array}$ & $0.416^{\star * \star}$ & $0.437^{* \star *}$ & $0.418^{\star \star \star}$ & $0.401^{\star \star \star}$ & $0.596^{\star \star}$ & 0.793 \\
\hline PTA $x$ Post & $0.385^{\star * *}$ & $0.399 * * *$ & $0.376^{\star \star \star}$ & $0.485^{\star \star}$ & 0.846 & 0.908 \\
\hline \multicolumn{7}{|c|}{ Unbalanced Panel } \\
\hline PTA $x$ Post & $0.432^{\star \star \star}$ & $0.427^{\star \star \star}$ & $0.415^{\star \star \star}$ & $0.455^{\star \star \star}$ & $0.590^{\star \star}$ & 0.739 \\
\hline
\end{tabular}

* significant at $10 \%$; ** significant at $5 \%$; ** significant at $1 \%$

Same specifications as in Table 2 but only the PTA effect coefficient is reported

Coefficients reported as incidence-rate ratios 
Table 9: Robustness Checks (by type of PTA Rules)

\begin{tabular}{|c|c|c|c|c|c|c|}
\hline & A & B & $\mathbf{C}$ & $\mathrm{D}$ & $E$ & $F$ \\
\hline \multicolumn{7}{|l|}{ Benchmark (Table 4) } \\
\hline AD Prohibited $x$ Post & 0 & 0 & 0 & 0 & 0 & 0 \\
\hline AD Rules x Post & $0.392^{* * *}$ & $0.393^{\star \star \star}$ & $0.361^{\star \star \star}$ & $0.299 * \star \star$ & $0.391^{* * *}$ & $0.441^{\star * *}$ \\
\hline AD No Rules x Post & 1.156 & 1.335 & 1.352 & 1.058 & 1.323 & 1.437 \\
\hline \multicolumn{7}{|l|}{ Year Dummies } \\
\hline AD Prohibited $x$ Post & 0 & 0 & 0 & 0 & 0 & 0 \\
\hline AD Rules $\times$ Post & $0.360 * * *$ & $0.360 * * \star$ & $0.335^{\star \star \star}$ & $0.255^{\star * \star}$ & $0.319 * * *$ & $0.362^{\star * *}$ \\
\hline AD No Rules $x$ Post & 1.283 & 1.579 & 1.522 & 1.152 & 1.507 & 1.549 \\
\hline \multicolumn{7}{|c|}{ Control for Uruguay Round } \\
\hline AD Prohibited $x$ Post & 0 & 0 & 0 & 0 & 0 & 0 \\
\hline AD Rules $x$ Post & $0.389 * * *$ & $0.407^{* * *}$ & $0.385^{\star \star \star}$ & $0.287^{\star \star \star}$ & $0.389 * \star \star$ & $0.452^{* * *}$ \\
\hline AD No Rules x Post & 1.132 & 1.306 & 1.311 & 1.024 & 1.274 & 1.376 \\
\hline \multicolumn{7}{|l|}{ Control for BITS } \\
\hline AD Prohibited $x$ Post & 0 & 0 & 0 & 0 & 0 & 0 \\
\hline AD Rules $\times$ Post & $0.390^{\star * *}$ & $0.381^{\star \star *}$ & $0.357^{\star * *}$ & $0.295^{\star \star *}$ & $0.372^{\star \star *}$ & $0.430^{* * *}$ \\
\hline AD No Rules $x$ Post & 1.172 & 1.323 & 1.348 & 1.074 & 1.303 & 1.424 \\
\hline \multicolumn{7}{|l|}{ Drop PRC } \\
\hline AD Prohibited $x$ Post & 0 & 0 & 0 & 0 & 0 & 0 \\
\hline AD Rules $x$ Post & $0.409 * * *$ & $0.400 * * \star$ & $0.364^{\star \star \star}$ & $0.312^{\star \star *}$ & $0.401^{\star \star \star}$ & $0.446^{\star * *}$ \\
\hline AD No Rules x Post & 1.207 & 1.368 & 1.382 & 1.105 & 1.359 & 1.47 \\
\hline \multicolumn{7}{|l|}{ Drop NAFTA } \\
\hline AD Prohibited $x$ Post & 0 & 0 & 0 & 0 & 0 & 0 \\
\hline AD Rules $\times$ Post & $0.456^{* * *}$ & $0.477^{* * *}$ & $0.454^{\star \star \star}$ & $0.425^{\star \star \star}$ & $0.555^{\star}$ & $0.533^{\star *}$ \\
\hline AD No Rules $x$ Post & 1.136 & 1.309 & 1.348 & 1.123 & 1.379 & 1.427 \\
\hline \multicolumn{7}{|l|}{ Drop EC/EU PTAs } \\
\hline AD Prohibited $x$ Post & 0 & 0 & 0 & 0 & 0 & 0 \\
\hline AD Rules $\times$ Post & $0.384^{\star * *}$ & $0.387^{\star * *}$ & $0.345^{\star \star *}$ & $0.312^{\star * *}$ & $0.460^{\star \star}$ & $0.478^{\star \star}$ \\
\hline AD No Rules $x$ Post & 1.163 & 1.347 & 1.353 & 1.094 & 1.417 & 1.487 \\
\hline \multicolumn{7}{|l|}{ Alternative Classification } \\
\hline AD Prohibited $x$ Post & 0 & 0 & 0 & 0 & 0 & 0 \\
\hline AD Rules $x$ Post & $0.408^{* * *}$ & $0.418^{* * *}$ & $0.378^{\star \star \star}$ & $0.353^{\star * *}$ & $0.561^{*}$ & $0.570^{*}$ \\
\hline AD No Rules $x$ Post & $0.447^{* * *}$ & $0.458^{\star \star \star}$ & $0.471^{\star \star \star}$ & $0.427^{\star \star \star}$ & $0.560^{\star}$ & $0.597^{\star}$ \\
\hline \multicolumn{7}{|l|}{ Fixed Effects } \\
\hline AD Prohibited $x$ Post & 0 & 0 & 0 & 0 & 0 & 0 \\
\hline AD Rules $x$ Post & $0.382^{* * *}$ & $0.402^{\star \star \star}$ & $0.379 * \star \star$ & $0.335^{\star \star *}$ & 0.513 & 0.516 \\
\hline AD No Rules $x$ Post & 1.173 & 0.996 & 0.931 & 1.138 & 1.082 & 1.033 \\
\hline \multicolumn{7}{|l|}{ Unbalanced Panel } \\
\hline AD Prohibited $x$ Post & 0 & 0 & 0 & 0 & 0 & 0 \\
\hline AD Rules $x$ Post & $0.451^{* * *}$ & $0.438^{\star * \star}$ & $0.404^{\star \star \star}$ & $0.433^{\star * *}$ & $0.560 * *$ & $0.638^{*}$ \\
\hline AD No Rules $x$ Post & 0.888 & 0.888 & 0.818 & 0.88 & 0.99 & 0.991 \\
\hline
\end{tabular}

* significant at 10\%; ** significant at $5 \%$; *** significant at $1 \%$

Same specifications as in Table 2 but only the PTA effect coefficient is reported Coefficients reported as incidence-rate ratios 
Table 10: AD Filings (balanced panel), collapse pre-/post-periods

\begin{tabular}{lc}
\hline & BDM \\
\hline PTA & 0.905 \\
& {$[0.892]$} \\
Post PTA Inception & 7.145 \\
& {$[0.007]^{\star \star *}$} \\
PTA x Post & 0.089 \\
& {$[0.020]^{\star *}$} \\
\hline Observations & 1,592 \\
Log Likelihood & -2131.9 \\
\hline Coefficients reported as incidence-rate ratios, $p$ values in brackets \\
* significant at 10\%; ** significant at 5\%; ${ }^{* *}$ significant at $1 \%$
\end{tabular}

